\title{
Improve Common Bean (Phaseolus vulgaris L.) Yield through Cattle Manure in Nioka Region, Ituri Province, DRC
}

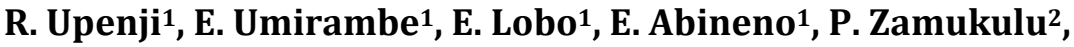 \\ P. B. Mushagalusa ${ }^{3}$, D. M. M. Katunga ${ }^{*}$
}

${ }^{1}$ Institut National pour l'Etude et la Recherche Agronomiques (INERA), Nioka, Kinshasa 1, RDC

${ }^{2}$ Faculté des Sciences Agronomiques et Environnement, Université Evangélique en Afrique (UEA), Bukavu, RDC, Bukavu, RDC ${ }^{3}$ Institut National pour l'Etude et la Recherche Agronomique (INERA) Mulungu DS Bukavu, DRC

Email: stylonya@gmail.com,patzamukulu2@gmail.com,*mushagalusapyame@gmail.com

How to cite this paper: Upenji, R., Umirambe, E., Lobo, E., Abineno, E., Zamukulu, P., Mushagalusa, P.B. and Katunga, D.M.M. (2020) Improve Common Bean (Phaseolus vulgaris L.) Yield through Cattle Manure in Nioka Region, Ituri Province, DRC. Open Access Library Journal, 7: e6610. https://doi.org/10.4236/oalib.1106610

Received: July 14, 2020

Accepted: September 14, 2020

Published: September 17, 2020

Copyright ( $) 2020$ by author(s) and Open Access Library Inc.

This work is licensed under the Creative Commons Attribution International License (CC BY 4.0).

http://creativecommons.org/licenses/by/4.0/

(c) (i) Open Access

\begin{abstract}
The agricultural production of common bean farmers in the DRC is deficient due to several factors: lack of plant disease control, poor farming practices, declining soil fertility and limited use of soil conservation measures such as the application of cattle manure to restore soil fertility. A complete randomized block experiment design with three replicates was carried out in Rimba and Lekpa sites in Ituri Province in order to observe the seed yield of three varieties of common bean (M'Sole, AFR 708 and Shabi rouge) during two cropping seasons (seasons B 2016 and A 2017) following the effects of using organic manure at dose of 0 and $5 \mathrm{t} / \mathrm{ha}$. Results showed that seed yield of common bean varieties fluctuated significantly according to the season, variety, manure input $(\mathrm{P}<0.05)$. Seeds yield means produced under manure application was $(953.94 \mathrm{~kg} / \mathrm{ha})$ and the local $(900.61 \mathrm{~kg} / \mathrm{ha})$. Season A 2017 was more productive $(927.28 \mathrm{~kg} / \mathrm{ha})$ than season B $2016(727.4 \mathrm{~kg} / \mathrm{ha})$. AFR 708 was the most productive variety in Rimba and Lekpa $(1231.66 \mathrm{~kg} / \mathrm{ha}$ and $926.58 \mathrm{~kg} / \mathrm{ha})$ and also in Season A 2017 and Season B $2016(1081.08 \mathrm{~kg} / \mathrm{ha}$ and $1077.16 \mathrm{~kg} / \mathrm{ha}$ ). Manure application appeared to be one of the main options that would improve common bean seed yield for food security.
\end{abstract}

\section{Subject Areas \\ Agricultural Science}

\section{Keywords}

Seeds Yield, Manure, Common Bean, Environment, Ituri 


\section{Introduction}

The common bean is a legume among one of the staple foods for urban and peri-urban population in most developing countries, particularly in the Democratic Republic of the Congo (DRC) where it is considered as one of the accompanying starchy foods [1] [2]. It is an excellent source of protein, vitamins and other essential nutrients for the nutritional balance of its consumers [3].

Common bean production faces several constraints limiting its yield with more than $0.7 \mathrm{t} /$ ha under rural conditions without using inputs [1] [4]. In addition, low soil fertility, diversity of plant pathologies, use of low-performance varieties, climate disturbance and use of inappropriate farming practices are also the main constraints limiting common bean production among smallholder farmers [5] [6] [7] [8]. However, the use of high genetic performance varieties as well as soil fertilization would contribute to increasing common bean productivity in the context of low arable land fertility [9]. Manure is available in Ituri villages but not often applied in agriculture.

The use of organic fertilizers appears to be one of the effective and sustainable options for increasing crop yields and improving soil quality in the context of integrated soil fertility management [10] [11]. Organic fertilizers as manure have become one of the most important sources of essential nutrients for crop growth and yield [12] [13]. It is the excellent source of soil macro and micronutrients for improved agricultural production while promoting good soil microbiological activity [14].

This study was undertaken to assess the effects of using farmyard manure as a fertilizer to increase the seed yield of common bean in Ituri Province, DRC.

\section{Methodology}

Study area. Trial was conducted in two experimental sites (Lekpa and Rimba) of the National Agricultural Research Centre INERA-Nioka (latitude North 02 $09^{\prime}$, longitude East: $30^{\circ} 39^{\prime}$, average altitude $1678 \mathrm{~m}$ asl) located at about $125 \mathrm{~km}$ from Bunia and $54 \mathrm{~km}$ from Mahagi-centre in the Ituri Province, DRC. Nioka region enjoys a climate of mountainous altitude, zone type $C$ according to the Kôppen classification. It receives an average annual rainfall of $1366 \mathrm{~mm}$ with an average temperature varying between $18^{\circ} \mathrm{C}$ and $25^{\circ} \mathrm{C}$. Soils origin is from granite [15].

Trial design. Experiment was conducted during season B 2016 and season A 2017 using a complete randomized block experiment design with three replications and two factors. The main factor was variety with three levels (M'Sole, Shabi rouge and AFR 708) and the secondary factor, manure input with two levels (5 t/ha and the local). Seeds were sowed in rows at $40 \mathrm{~cm} \times 20 \mathrm{~cm}$ with 2 seeds per plot, pathway was $1 \mathrm{~m}$ between plots. Observations parameters were made on germination rate, day's number of physiological ripeness, number of pods per plant and seed yield.

Biological material. The common bean varieties; M'sole, Shabi rouge and AFR 708 were disseminated by INERA Mulungu research centre since 2000 and 
adopted by small farmers in Sud-Kivu. They adapt well in different agro-ecological conditions, with good resistance to plant pathologies present in the environment.

Organic fertilizer. Cattle manure from the INERA-Nioka farm was used at a dose of $5 \mathrm{t} / \mathrm{ha}$. The composition of this manure was considered to be closed to manure from INERA-Mulungu, with $20.1 \%$ C; $2.3 \% \mathrm{~N} ; 0.19 \%$ P; $2.4 \% \mathrm{~K} ; 1.3 \%$ Ca; $0.50 \% \mathrm{Mg}$ and $0.31 \% \mathrm{~S}$ [10].

Data analysis. Data were encoded using Microsoft Excel. Analysis of variance (ANOVA) was performed with GenStat software and means were compared with the Least Significant Difference (LSD) test by the Statistix version 8.0 software.

\section{Results}

Table 1 shows analysis of combined variances of the growth and yield parameters.

Table 1. Average effect on the growth and yield parameters.

\begin{tabular}{|c|c|c|c|c|c|c|}
\hline \multicolumn{2}{|c|}{ Main factors } & GR & NDPM & NPP & W100G (g) & Yied $(\mathrm{kg} / \mathrm{ha})$ \\
\hline \multicolumn{7}{|c|}{ Season B 2016} \\
\hline \multirow[t]{4}{*}{ Varieties } & AFR 708 & 83.36 & 91.25 & $11.08^{\mathrm{a}}$ & $59.00^{\mathrm{b}}$ & $660.50^{c}$ \\
\hline & M'Sole & 78.89 & 91.75 & $10.50^{\mathrm{ab}}$ & $25.50^{c}$ & $740.00^{\mathrm{b}}$ \\
\hline & Shabi rouge & 83.53 & 91.50 & $10.17^{\mathrm{b}}$ & $57.33^{\mathrm{a}}$ & $781.71^{\mathrm{a}}$ \\
\hline & $L S D$ & 5.35 & & 0.722 & 2.040 & 333.4 \\
\hline \multirow[t]{3}{*}{ Manure } & Local & 81.08 & 92.83 & $11.00^{\mathrm{a}}$ & $50.72^{\mathrm{a}}$ & $803.08^{\mathrm{a}}$ \\
\hline & Manure & 82.78 & 90.16 & $10.17^{\mathrm{b}}$ & $43.83^{\mathrm{b}}$ & $651.72^{\mathrm{b}}$ \\
\hline & $L S D$ & 4.47 & & 0.590 & 1.666 & 272.2 \\
\hline \multirow[t]{3}{*}{ Sites } & Lekpa & 74.74 & 91.50 & $6.22^{\mathrm{b}}$ & $46.72^{\mathrm{a}}$ & $616.22^{\mathrm{b}}$ \\
\hline & Rimba & 89.11 & 91.50 & $14.94^{\mathrm{a}}$ & $47.83^{\mathrm{a}}$ & $838.58^{\mathrm{a}}$ \\
\hline & $L S D$ & 4.37 & & 0.590 & 1.666 & 272.2 \\
\hline \multicolumn{7}{|c|}{ Season A 2017} \\
\hline \multirow[t]{4}{*}{ Varieties } & AFR 708 & 87.71 & 90.41 & $12.00^{\mathrm{a}}$ & $56.08^{\mathrm{ab}}$ & $910.2^{\mathrm{a}}$ \\
\hline & M'Sole & 81.93 & 91.50 & $11.17^{\mathrm{ab}}$ & $24.42^{\mathrm{b}}$ & $1063.8^{\mathrm{a}}$ \\
\hline & Shabi rouge & 87.39 & 90.50 & $11.00^{\mathrm{b}}$ & $56.42^{\mathrm{a}}$ & $807.7^{\mathrm{a}}$ \\
\hline & $L S D$ & 2.295 & 0.813 & 0.889 & 0.937 & 180.7 \\
\hline \multirow[t]{3}{*}{ Manure } & Local & 85.17 & 91.88 & $11.67^{\mathrm{a}}$ & $49.28^{\mathrm{a}}$ & $953.94^{\mathrm{a}}$ \\
\hline & Manure & 86.18 & 89.72 & $11.11^{\mathrm{a}}$ & $42.00^{\mathrm{b}}$ & $900.61^{a}$ \\
\hline & $L S D$ & 1.874 & 0.664 & 0.726 & 0.765 & 147.6 \\
\hline \multirow[t]{3}{*}{ Sites } & Lekpa & 77.54 & 90.88 & $7.78^{\mathrm{b}}$ & $45.17^{\mathrm{b}}$ & $1019.8^{\mathrm{a}}$ \\
\hline & Rimba & 93.82 & 90.72 & $15.00^{\mathrm{a}}$ & $46.11^{\mathrm{a}}$ & $834.8^{\mathrm{b}}$ \\
\hline & $L S D$ & 1.874 & 0.664 & 0.726 & 0.765 & 147.6 \\
\hline
\end{tabular}

LSD: Least significant difference; GR: germination rate; NDPM: days number to physiological ripeness; NPP: number of pods per plant; W100G: weight of hundred seeds, Means with the same letters within the same column do not differ significantly $(\mathrm{P}>0.05)$. 
The results in Table 1 showed means germination rates varied between $74.7 \%$ in the first season to $93.8 \%$ in the second season. Means day numbers to physiological ripeness varied also form 89.72 in the second season to 92.83 during the first season. Parameters of growth and yield of common bean varied significantly from season to season. During season B 2016, Shabi rouge variety has high seed yield (781.71 kg/ha) compared to AFR 708 variety $(660.50 \mathrm{~kg} / \mathrm{ha})$ which produced less. The plots that received manure obtained a better seed yield ( 803.08 $\mathrm{kg} / \mathrm{ha})$ than the control $(651.72 \mathrm{~kg} / \mathrm{ha})$. Rimba site had more seed yield ( 838.58 $\mathrm{kg} / \mathrm{ha}$ ) compared to Lekpa (616.22 kg/ha). During A 2017 season, M'Sole variety had the most seed yield $(1063.8 \mathrm{~kg} / \mathrm{ha})$ and Shabi rouge variety the least seed yield $(807.7 \mathrm{~kg} / \mathrm{ha})$. There was a significant difference $(\mathrm{P}<0.05)$ between the means of seeds yield under manure $(953.94 \mathrm{~kg} / \mathrm{ha})$ and the local $(900.61 \mathrm{~kg} / \mathrm{ha})$. Lekpa produced more seeds yield $(1019.8 \mathrm{~kg} / \mathrm{ha})$ than Rimba $(834.8 \mathrm{~kg} / \mathrm{ha})$.

Results in Table 2 showed that seeds yield varied significantly depending on the season. Seed yield was higher in A 2017 season $(927.28 \mathrm{~kg} / \mathrm{ha})$ than in B 2016 season $(727.40 \mathrm{~kg} / \mathrm{ha})$.

ANOVA in Figure 1 showed that seed yield varied significantly $(\mathrm{P}<0.001)$ depending on the season-site interaction. At Lekpa, season A 2017 has more seed yield (1019.77 kg/ha) than in season B 2016 (616.22 kg/ha) and at Rimba, season B 2016 has more seed yield ( $838 \mathrm{~kg} / \mathrm{ha}$ ) compared to season A 2017 (834 kg/ha).

ANOVA in Figure 2 showed that seed yield has significant variation according to the season-varieties interaction $(\mathrm{P}<0.05)$. Shabi rouge variety performed with high seed yield $(781.71 \mathrm{~kg} / \mathrm{ha})$ comparative to M'Sole $(740 \mathrm{~kg} / \mathrm{ha})$ and AFR

Table 2. Effect of the cultural season on growth and yield parameters during two growing seasons.

\begin{tabular}{cccccc}
\hline Season & GR & NDPR & NPP & W100G (g) & Yield (kg/ha) \\
\hline Season B 2016 & $81.93^{\mathrm{b}}$ & $91.500^{\mathrm{b}}$ & $10.583^{\mathrm{b}}$ & $47.278^{\mathrm{b}}$ & $727.40^{\mathrm{b}}$ \\
Season A 2017 & $85.68^{\mathrm{a}}$ & $90.806^{\mathrm{a}}$ & $11.389^{\mathrm{a}}$ & $45.639^{\mathrm{a}}$ & $927.28^{\mathrm{a}}$ \\
LSD & 2.270 & 0.3599 & 0.504 & 0.889 & 102.1 \\
CV (\%) & 11.35 & 1.69 & 38.84 & 35.06 & 42.4 \\
\hline
\end{tabular}

Legend 2: GR: Germination rate; NDPR: number of days to physiological ripeness; NPP: number of pods per plant; W100G: weight of hundred seeds, LSD: Least significant difference, VC: variation coefficient, Means with the same letters within the same column do not differ significantly $(\mathrm{P}>0.05)$.

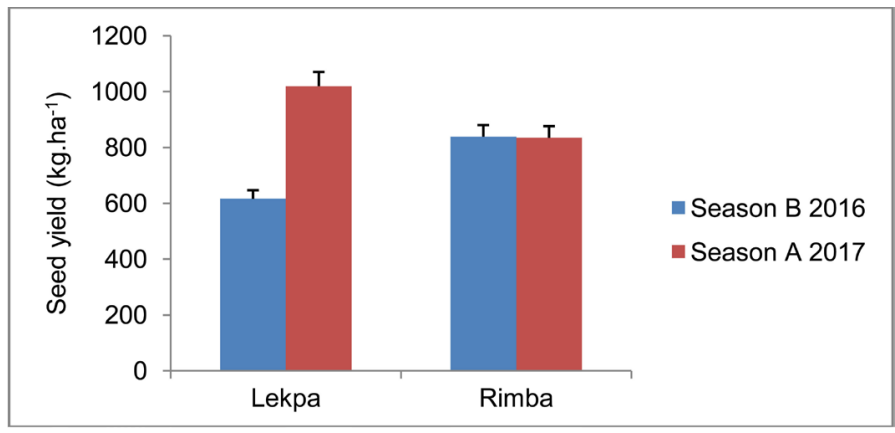

Figure 1. Effect of season-site interaction on the seed yield “***”. 
$708(660 \mathrm{~kg} / \mathrm{ha})$ varieties in B 2016. In A 2017 season the M'Sole variety has more seed yield $(1063.8 \mathrm{~kg} / \mathrm{ha})$ than AFR $708(910.2 \mathrm{~kg} / \mathrm{ha})$ and Shabi rouge $(807.7 \mathrm{~kg} / \mathrm{ha})$ varieties.

ANOVA in Figure 3 showed that the common bean seeds yield varied significantly depending on the interaction between site-varieties $(P<0.001)$ : yields were classified in the same way regardless of the site (AFR $708>$ M'Sole $>$ Shabi rouge), while Rimba was better for AFR 708.

Results on seed yield of common bean as a function of the season-site-variety interaction are presented in Figure 4.

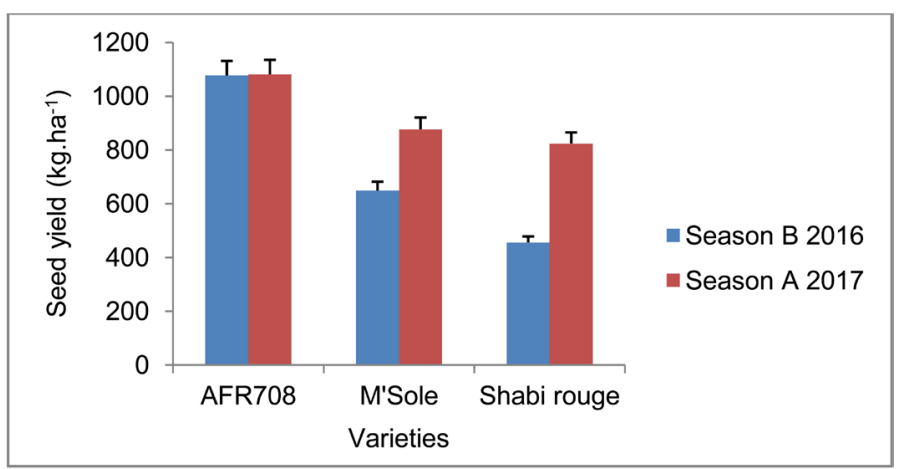

Figure 2. Effect of season-varieties interaction on the seed yield “»”.

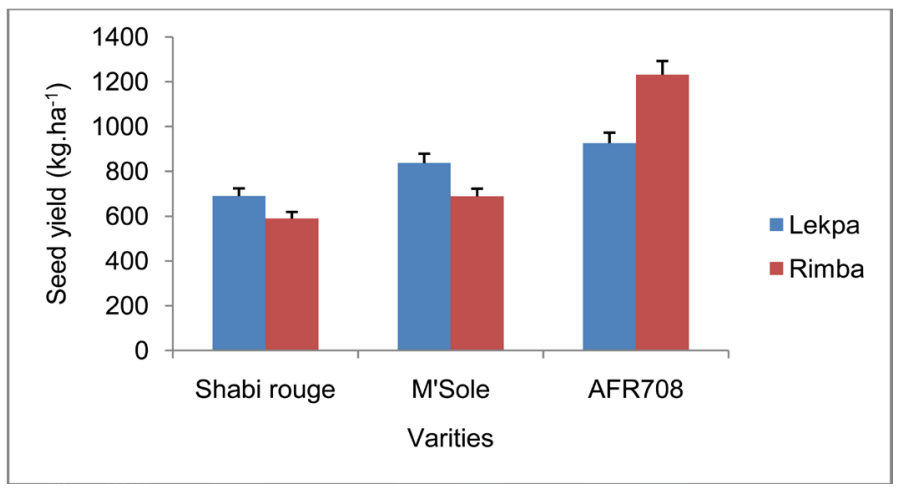

Figure 3. Effect of the interaction site-varieties on the seed yield of common bean " $* * *$ ".

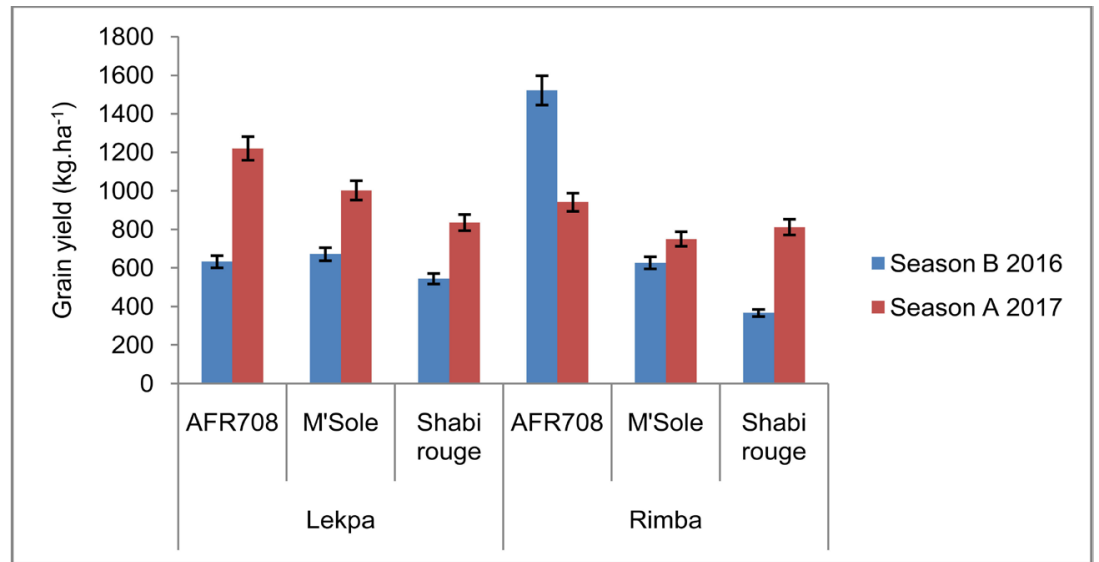

Figure 4. Effect of season-site-variety interaction on Common bean seed yield “**”. 
ANOVA in Figure 4 showed that common bean seed yield varied significantly as a function of season-site-variety interaction $(\mathrm{P}<0.01)$. The highest yield was obtained by variety AFR 708 (1521.83 kg/ha) in season B 2016 in Rimba site while the lowest obtained with Shabi variety rouge in season B 2016 was also in Rimba (366.917 kg/ha).

\section{Discussion}

Effect of varieties and site. Results showed that bean seed yield varied significantly by variety $(\mathrm{p}$-value $=0.05)$. Difference in seed yield due to varieties shall be explained by the genetic performance that each variety has to adapt to different environmental conditions. These results were supported by [5] who demonstrated that seed yield of common beans varied significantly between varieties during different cropping seasons in different agro-ecological zones of North and Sud-Kivu. Genetic performance is one of indicators for agricultural production, since each variety has its own capacity to produce a potential yield in different agro-ecological areas [16] [17] [18] [19].

Effect of cropping seasons. Results showed that bean seed yield means varied very significantly with the seasons $(\mathrm{P}<0.001)$. Similar results were obtained in Kashusha (Sud-Kivu) by [8] who showed that yield of biofortified common bean seeds was higher during the long rainy season (season $A$ ) than in the short one (season B). Uddin et al. obtained results similar on Lablab by demonstrating that the growing seasons had a significant influence on the yield [20]. Environmental factors, particularly the growing season, play a major role in the yield crops.

Effect of manure application. Common bean seed yield varied significantly $(\mathrm{P}<0.05)$ as a function of cattle manure input during two cropping seasons in the two agro-ecological zones. The use of manure as an organic fertilizer produced high seed yield than the control [21] [22]. Similar results were obtained on Vigna radiata L. in Nepal by [23]. These results are supported by [24] who had obtained a significant difference $(\mathrm{P}<0.05)$ in seed yield.

Limitations about this study. Climate and soils data presented in Materials and methods section are general vis-à-vis of the sites where trials were implemented. This is due to scarcity of meteorological materials and our center which doesn't have a soil laboratory. However, [8] observed like us that in Sud-Kivu, DRC season A was most productive than season B.

\section{Conclusion}

Trial examined during two growing seasons how seeds yield of three common bean varieties can be increased by applying manure in Rimba and Lekpa sites at Nioka region, Ituri Province, DRC. Significant difference $(P<0.05)$ was observed between the means of seeds yield under manure application (953.94 $\mathrm{kg} / \mathrm{ha})$ and the local $(900.61 \mathrm{~kg} / \mathrm{ha})$. Common beans were more productive in season A 2017 (927.28 kg/ha) than in season B 2016 (727.40 kg/ha). In addition, AFR 708 was the most productive variety in Rimba and Lekpa (1231.66 kg/ha 
and $926.58 \mathrm{~kg} / \mathrm{ha}$ ) compared to other varieties examined. AFR 708 was the most productive in Season A 2017 and Season B 2016 (1081.08 kg/ha and 1077.16 $\mathrm{kg} / \mathrm{ha}$ ) compared to other varieties that responded differently from season to season. Manure fertilizer is then recommended to farmers in Nioka region to improve their common bean seeds yield.

\section{Acknowledgements}

Our acknowledgements are going to INERA-Nioka Research center for the funding of this research.

\section{Conflicts of Interest}

The authors declare no conflicts of interest regarding the publication of this paper.

\section{References}

[1] Rehani, J., Njukwe, E., Dontsop-Nguezet, P.-M., Lubobo, A., Zamukulu, P. and Gomintan, M. (2016) Evaluation of Bean (Phaseolus vulgaris L.) Germplasms in Two Agro-Ecological Zones of the DR Congo. Pan-African Gran Legumes et World Cowpea Conference, Tanzania. https://www.researchgate.net/publication/298396864

[2] Mondo, J., Kimani, P. and Nrala, R. (2019) Validation of Effectiveness Market-Assisted Gamete Selection for Multiple Disease Resistance in Common Bean. African Crop Science Journal, 27, 585-612.

https://www.researchgate.net/publication/336699003 https://doi.org/10.4314/acsj.v27i4.4

[3] Turuko, M. and Mohammed A. (2014) Effect of Different Phosphorus Fertilizer Rates on Growth, Dry Matter Yield and Yield Components of Common Bean (Phaseolus vulgaris L.). World Journal of Agricultural Research, 2, 88-92. https://doi.org/10.12691/wjar-2-3-1

[4] Casinga, C., Haminosi, G. and Cirimwami, L. (2017) Determining Optimal Dose of Chemical Fertilizer on Biofortified Bean in Sud-Kivu Highlands. Journal of Agricultural Science, 9, 128-133. https://doi.org/10.5539/jas.v9n1p128

[5] Lunze, L., Abang, M., Buruchara, R., Ugen, M., Nabahungu, L., Rachier, G., Ngongo, M. and Rao, I. (2012) Integrated Soil Fertility Management in Bean-Based Cropping Systems of Eastern, Central and Southern Africa. In: Whalen, J., Ed., Soil Fertility Improvement Management and Integrated Nutrient Management-Global Perspective, IntechOpen, London, 306 p. https://doi.org/10.5772/29151

[6] Mirindi, C., Mbikayi, N., Kijana, R., Elukessu, K., Bakulikira, R., Koleramungu, Mongana, E. and Rubabura, J. (2015) Behaviour and Adaptation of Biofortified Common Bean Varieties (Phaseolus vulgaris L.) in Agroecological Zones of Nord et Sud-Kivu, East RDC. International Journal of Innovation and Scientific Research, $18,252-261$.

[7] Lubobo, A., Kasongo, E., Kizungu, R., Nachigera, G. and Kalonji, A. (2016) Effect of Climate Change on Common Bean (Phaseolus vulgaris) Crop Production: Determination of the Optimum Planting Period in Midlands and Highlands Zones of the Democratic Republic of Congo. Global Journal of Agricultural Research and Reviews, 4, 190-199. 
[8] Mushagalusa, G., Kashemwa, A., Sinza, C., Bigirimwami, L., Karume, K. and Lubobo, A. (2016) Responses of Biofortified Common Bean Varieties to Diammonium Phosphate Fertilizer under Climate Variability Conditions in South-Kivu, DR Congo. African Journal of Agricultural Research, 11, 3569-3577. https://doi.org/10.5897/AJAR2016.11295

[9] Balagizi, I., Chifizi, A., Bagula, E., Cizungu, J., Mirindi, T., Masilya, P. and Isumbisho, P. (2013) Fertilisation Effect "CETEP" on Cropping Common Bean in Sud-Kivu. VertigO la revue électronique en sciences de l'environnement. http://vertigo.revues.org/13914

[10] Bagula, E., Pypers, P., Mushagalusa, G. and Muhigwa, J.-B. (2014) Assessment of Fertilizer Use Efficiency of Maize in the Weathered Soils of Walungu District, DR Congo. In: Vanlauwe, B., et al., Eds., Challenges and Opportunities for Agricultural Intensification of the Humid Highland Systems of Sub-Saharan Africa, Springer International Publishing, Berlin, 187-199.

https://doi.org/10.1007/978-3-319-07662-1 16

https://www.researchgate.net/publication/290973965

[11] Kavange, A., Cishesa, T., Zamukulu, P., Kulimushi, J. and Ganza, D. (2018) Effects of Interval and Organic Manure on the Yield of Irish Potatoes (Solanum tuberesom L.) in Walungu, East RDC. Afrique SCIENCE, 14, 316-322. https://www.researchgate.net/publication/333816296

[12] Ndjadi, S., Mirindi, B., Musafiri, P., Chuma, G., Cinyabuguma, E. and Bisimwa, E. (2016) Evaluation of the Productivity of Wheat (Triticum aestivum) through Integrated Soil Fertility Management in Kaziba, South Kivu, DR Congo. Field Actions Science Reports, 9, 10 p. http://factsreports.revues.org/4244

[13] Zamukulu, P., Njukwe, E., Bagula, E., Ayagirwe, A., Jumaine, J., Dontsop-Nguezet, P. and Mushagalusa, G. (2016) Effects of Fertilisers on Cassava and Common Bean Yield Intercropped in Walungu, East of DRC. Pan-African Gran Legumes et World Cowpea Conference, Zambia, 27 February-4 March 2016. https://www.researchgate.net/publication/333866926

[14] Acharya, S. and Kumar, H. (2018) Effect of Some Organic Manure on Growth and Yield of Garlic in Greenhouse Condition at Cold Desert High Altitude Ladakh Region. Defense Life Science Journal, 3, 100-104. https://doi.org/10.14429/dlsj.3.12569

[15] Liben, L. and Sperry, T. (1954) Soils and Vegetation Map of Belgian Congo, Rwanda and Burundi, 4 Nioka Explanation, Note of Soils and Vegetations Map of Ituri A,B,C. Publications of INEAC, Bruxelles, 31 .

[16] Casinga, C., Cirimwami, L., Amzati, G., Katembera, J., Lubobo, A. and Mushagalusa, G. (2015) Effect of Environment on the Adaptability of Biofortified BEN Genotypes in the Eastern Democratic Republic of Congo: Case of South Kivu. European Journal of Agriculture and Forestry Research, 3, 38-47.

[17] Casinga, C., Cirimwami, L., Amzati, G., Kaningini, E. and Lubobo, A. (2016) Hydric Effects of Varietal Screening of Common Beans (Phaseolus vulgaris) in the Mountain Swamps of Sud Kivu. Afrique SCIENCE, 12, 335-344.

[18] Chantiro, S., Bokosi, J., Mkwaila, W. and Chirwa, R. (2016) Water Stress Effect on Common Bean Genotypes with Four Growth Habits. Ruforum Working Document Series, 14, 779-785.

[19] Oljira, A., Gedebo, A. and Mohammed, H. (2016) Evaluation of Red Common Bean (Phaseolus vulgaris) Genotypes for Yield and Yield Traits in Borecha District of Sidama Zone, Southern Ethiopia. Global Journal of Science Frontier Research: $D$ Agriculture and Veterinary, 16, 43-50. 
[20] Uddin, Z., Chowdhurry, A., Hossain, M. and Moniruzzaman, M. (2007) Seasonal Influence on Yield and Yield Contributing Characters of Lablab Bean (Lablab purpureus (L) Sweet). The Agriculturists, 5, 109-119. https://doi.org/10.3329/agric.v5i1.5205

[21] Bahati, D., Birali, M., Masirika, C., Bisimwa, E., Mulumuna-wa-Lola, J., Heri-Kazi, A., Walangululu, J. and Obedi, N. (2014) Fertilisation Effect on the Yield and the Concentration of Nutrients on Biofortify Common Beans. Cahiers du CERUKI, Nouvelle série, 44, 241-254.

[22] Pypers, P., Sanginga, J.-M., Kasereka, B., Walangululu, J. and Vanlauwe, B. (2011) Increased Productivity through Integrated Soil Fertility Management in Cassava-Legume Intercropping Systems in the Highlands of Sud-Kivu, DR Congo. Field Crops Research, 120, 76-85. https://doi.org/10.1016/j.fcr.2010.09.004

[23] Ojha, R., Shah, S., Pande, K. and Dhakal, D. (2014) Residual Effect of Farm Yard Manure on Soil Properties in Spring Season, Chitwan, Nepal. International Journal of Scientific Research in Agricultural Sciences, 1, 165-171. https://doi.org/10.12983/ijsras-2014-p0165-0171

[24] Mahabub, S., Khan, S., Maed, H., Sarker, S. and Tereque, H. (2016) Effect of Cow Manure on Growth, Yield and Nutrient Content of Mungben. Asian Research Journal of Agriculture, 2, 1-6. https://doi.org/10.9734/ARJA/2016/29297 